\title{
E-FILLING DAN RELAWAN PAJAK DALAM MENINGKATKAN KEPATUHAN WAJIB PAJAK ORANG PRIBADI
}

\author{
I Nyoman Darmayasa ${ }^{1}$, Bagus Putra Wibawa ${ }^{2}$ Ketut Nurhayanti $^{3}$ \\ 1,2,3 Jurusan Akuntansi, Politeknik Negeri Bali \\ nyomandarmayasa@pnb.ac.id
}

\begin{abstract}
This research aims to analyze the effect of e-filling application and tax volunteer's role to individual taxpayer's compliance. In addition, this research also analyzes the effect of tax volunteer's role as moderating variable on e-filling application to individual taxpayer's compliance. This research analyzes primary data from distributed questionnaires to 100 individual taxpayers' in assistance locations of Tax Volunteer from Politeknik Negeri Bali Tax Center. Sample selection in this research using purposive sampling technique. The testing of research variables was conducted using the Partial Least Square method with SmartPLS 3.0 application. The results showed that e-filling application and tax volunteers role had a positive and significant effect on individual taxpayer's compliance. While there is no significant effect from the moderation of tax volunteer's role in e-filling application to individual taxpayer's compliance. This research has a novelty the role of tax volunteers in improving taxpayer compliance. Furthermore, this research has a practical contribution to the tax authority to increase the role of tax volunteers and to taxpayers on the participation of utilizing tax volunteers to improve compliance.
\end{abstract}

Keywords: E-filling; Individual taxpayer; Tax compliance; Tax volunteer

\section{Abstrak}

Penelitian ini bertujuan untuk menguji efek dari penerapan e-filling dan peran relawan pajak terhadap kepatuhan wajib pajak orang pribadi. Di samping itu, dilakukan pula pengujian moderasi relawan pajak atas pengaruh penerapan e-filling terhadap kepatuhan wajib pajak orang pribadi. Penelitian ini menganalisis data primer dari kuesioner yang disebarkan kepada 100 wajib pajak orang pribadi di lokasi asistensi Relawan Pajak Tax Center Politeknik Negeri Bali. Pemilihan sample pada penelitian ini menggunakan teknik purposive sampling. Pengujian variabel penelitian dilakukan menggunakan metode Partial Least Square dengan aplikasi SmartPLS 3.0. Hasil penelitian menunjukkan bahwa penerapan e-filling dan peran relawan pajak berpengaruh positif dan signifikan terhadap kepatuhan wajib pajak orang pribadi. Sedangkan terdapat pengaruh yang tidak signifikan pada moderasi peran relawan pajak atas penerapan e-filling terhadap kepatuhan wajib pajak orang pribadi. Penelitian ini memiliki keterbaruan peran relawan pajak dalam meningkatkan kepatuhan wajib pajak. Penelitian ini memiliki kontribusi praktis pada otoritas pajak untuk meningkatkan peran relawan pajak dan terhadap wajib pajak pada partisipasi memanfaatkan relawan pajak untuk meningkatkan kepatuhan.

Kata Kunci: E-filling; Kepatuhan pajak; Relawan pajak; Wajib pajak orang pribadi

Cronicle of Article: Received (August); Revised (November); and Published (December).

(C2020 Jurnal Kajian Akuntansi Lembaga Penelitian Universitas Swadaya Gunung Jati.

Profile and corresponding author: I Nyoman Darmayasa, Bagus Putra Wibawa, and Ketut Nurhayanti are from Accounting Department Politeknik Negeri Bali. Corresponding Author: nyomandarmayasa@pnb.ac.id

How to cite this article: Darmayasa, I,N., Wibawa, B,P., \& Nurhayanti, K. (2020). E-filling dan Relawan Pajak Dalam Meningkatkan Kepatuhan Wajib Pajak Orang Pribadi. Jurnal Kajian Akuntansi 4 (2), 208 - 227 


\section{PENDAHULUAN}

Pajak merupakan tulang punggung pendapatan negara yang berjasa dalam pembiayaan dan pembangunan nasional di Indonesia. Kurang lebih $84 \%$ dari struktur Anggaran Pendapatan dan Belanja Negara (APBN) diperoleh dari penerimaan pajak. Menurut laporan kinerja Direktorat Jenderal Pajak (DJP) 2019, persentase capaian penerimaan pajak sampai dengan Desember 2019 hanya mampu dipenuhi sebesar 84\% dari target penerimaan dalam APBN. Perjuangan merealisasikan target penerimaan pajak tidak bisa dianggap enteng. Perlu dijalin komitmen dan komunikasi yang baik antara otoritas pajak dengan wajib pajak (WP).

Penelitian oleh Syakura \& Baridwan (2014) menyebutkan bahwa kepatuhan pajak berpengaruh terhadap realisasi penerimaan pajak. Mengingat peningkatan kepatuhan pajak merupakan cerminan dari kebijakan yang berpihak (Darmayasa, 2019; Darmayasa et al., 2018). Maka kepatuhan pajak dapat dikatakan memiliki peran sentral dalam pencapaian kesejahteraan hidup masyarakat (Nurwanah et al., 2018). Namun di Indonesia, kepatuhan pajak masih dalam kategori rendah. Padahal ada potensi pajak Indonesia yang dapat digali sebesar 57\% (Fenochietto \& Pessino, 2013). Setelah tahun 2017, kepatuhan pajak di Indonesia mengalami penurunan sebagaimana ditunjukkan dalam grafik perkembangan rasio kepatuhan pajak pada Gambar 1.

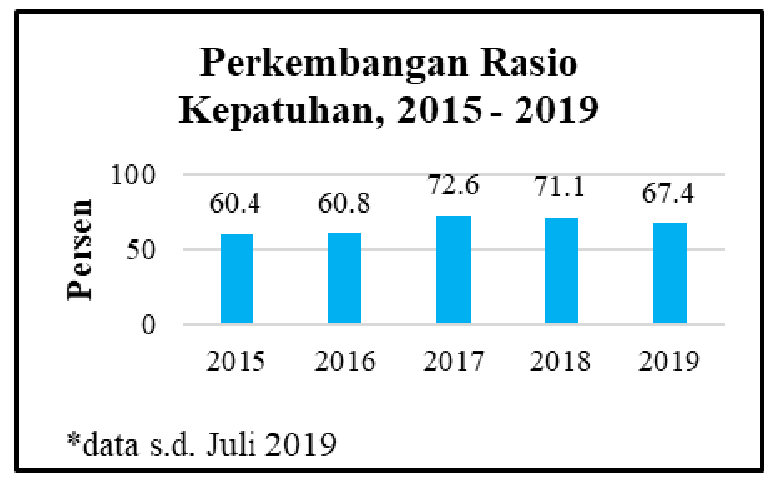

Gambar 1. Perkembangan Rasio Kepatuhan

Sumber: Nota Keuangan beserta RAPBN 2020
Menyikapi penurunan tersbeut, Kementerian Keuangan bersama DJP secara berkesinambungan melaksanakan reformasi pajak secara menyeluruh. Reformasi tersebut meliputi lima pilar utama yaitu organisasi, sumber daya manusia (SDM), teknologi informasi dan basis data, proses bisnis, dan peraturan perundang-undangan. Awal mula dari reformasi pajak ditandai dengan diterapkannya Self-Assestment System $(S A S)$ pada tahun 1983 di Indonesia. Pelaksanaan $S A S$ yang baik tentu dapat meningkatkan kepatuhan WP, khususnya dalam menyampaikan Surat Pemberitahuan (SPT) (Asrinanda, 2018). Dengan diterapkannya $S A S$ diperlukan kompetensi, kejujuran, kapabilitas, dan kesiapan WP dalam memperhitungkan beban pajak terutang. Artinya, WP harus memiliki pengetahuan yang memadai untuk menilai kewajiban pajak mereka dengan benar (Palil, 2011). Namun banyak orang berpendapat bahwa perpajakan adalah subjek yang sulit untuk dipelajari dan bahkan tidak sedikit yang enggan untuk memperluas pengetahuan perpajakan mereka (Palil, 2010). Selain itu jumlah dokumen yang harus diselesaikan WP dalam melaksanakan kewajiban perpajakannya semakin menuntun mereka ke arah ketidakpatuhan pajak (Saad, 2014).

Jika ditinjau kembali ternyata sistem administrasi pajak di Indonesia yang semula manual masih memiliki banyak kelemahan. WP acapkali mengalami kendala dalam menyelesaikan peyampaian SPT secara tepat waktu. Hal tersebut terjadi karena sistem pelaporan manual mengharuskan WP untuk melaporkan SPT secara langsung ke Kantor Pelayanan Pajak (KPP) yang tentu memiliki keterbatasan jam kerja (Teza \& Junep, 2018). Salah satu strategi tepat yang dilakukan DJP guna menyikapi masalah tersebut adalah dengan melakukan modernisasi sistem perpajakan. Salah satu wujud implementasi moderenisasi sistem perpajakan yang dilakukan oleh DJP yakni melalui penyediaan layanan e-filling. 
E-filling memiliki perananan yang sangat penting untuk memperoleh kepatuhan WP (Tambun \& Kopong, 2017). Pernyataan tersebut sejalan dengan penelitian pada WP di Kabupaten Badung oleh Sentanu \& Budiartha (2019) yang menyatakan bahwa semakin banyak WP menggunakan e-filling maka semakin bertambah pula tingkat kepatuhan WP.

Dalam dua tahun terakhir, jika dilihat dari sisi pertumbuhan pelaporan SPT, kepatuhan pajak di Indonesia tumbuh ke arah yang positif. Hingga 31 Maret 2019, SPT yang masuk naik 7,8 persen dibanding periode yang sama di tahun 2018 Peningkatan ini terjadi seiring digitalisasi administrasi perpajakan di Indonesia. Namun, sepuluh persen dari jumlah WP yang melaporkan SPT masih belum memanfaatkan e-filling (Kementerian Keuangan Republik Indonesia, 2020). Salah satu alasannya ialah kurangnya pengetahuan WP akan teknologi maupun internet dan kurang pahamnya WP tentang hak dan kewajiban masing-masing WP itu sendiri (Kaniskha et al., 2016). Pendapat tersebut sejalan dengan penelitian Hastuti et al. (2014) yang menyatakan bahwa sebenarnya WP di Indonesia menyadari bahwa e-filling dapat meningkatkan efektivitas pelaporan pajak mereka. Namun mereka tetap enggan menggunakan e-filling, dikarenakan tidak sedikit yang masih belum mengerti bagaimana cara mengoperasikan e-filling.

Kali ini DJP mencoba melibatkan masyarakat non-otoritas dalam suatu program yang digelar guna tercapainya peningkatan kepatuhan WPOP. Program tersebut disebut dengan relawan pajak (tax volunteer). Relawan pajak sebenarnya bukan merupakan program yang murni baru, kita dapat menemui program-program sejenis dengan nama yang berbeda di negara lain. Contohnya seperti program Volunteer Income Tax Assistance (VITA) di Amerika Serikat. VITA merupakan sebuah wujud inisiatif peningkatan layanan publik yang memanfaatkan kemajuan teknologi untuk melayani warga berpenghasilan rendah
(Carter et al., 2016). Selain bermanfaat bagi WP di Amerika Serikat menurut penelitian yang dilakukan oleh Boneck et al. (2014) tekait VITA, pengalaman yang didapat oleh mahasiswa akuntansi Southern Utah University yang tergabung pada VITA mampu menambah keahlian profesional mereka. Relawan pajak yang merupakan program sejenis diharapkan mampu memberikan manfaat-manfaat bagi segenap pihak yang terkait. Baik itu WPOP, relawan pajak, dan otoritas pajak. Maka dari itu perlu adanya pembinaan dan pelatihan untuk para relawan agar nantinya dapat bekerja secara optimal (Pradnyani \& Utthavi, 2020). Mengingat pelatihan yang efektif dan efisien dapat mempengaruhi kepuasan WP yang mengantarkan kepada kepatuhan (Dwianika \& Sofia, 2019).

Kegiatan relawan pajak yang dilaksanakan oleh Tax Center Politeknik Negeri Bali merupakan hasil kerjasama antara Tax Center dan Kantor Wilayah (Kanwil) DJP Bali. Tax Center perguruan tinggi nantinya akan menaungi dan memastikan program kerja relawan pajak berjalan baik setiap tahunnya (Dwianika \& Sofia, 2019). Kegiatan ini telah terlaksana sebanyak dua kali, yaitu pada tahun 2019 dan 2020. Mahasiswa yang lolos tahap seleksi akan dibekali dengan pengetahuan dasar perpajakan dan pelatihan softskill. Selain itu relawan juga diajarkan cara pelaporan SPT WPOP via e-filling. Keterampilan ini dapat diterapkan nantinya untuk melaksanakan tugas utama relawan pajak, yakni asistensi WPOP dalam melaporkan SPT Tahunan.

Pentingnya penerapan e-filling dan peran relawan pajak guna mengatasi masalah kepatuhan WP di Indonesia yang rendah, menyebabkan perlu dilakukan kajian ilmiah terhadap situasi tersebut. Dalam penelitian ini akan diuji pengaruh dari penerapan $e$ filling terhadap kepatuhan WPOP dan pengaruh peran relawan pajak terhadap kepatuhan WPOP, serta menguji pengaruh peran relawan pajak sebagai variabel moderasi atas penerapan e-filling terhadap kepatuhan WPOP. 


\section{KAJIAN PUSTAKA \\ Teori Atribusi}

Memahami perilaku suatu individu tidak terlepas dari teori yang mendasari terbentuknya sebuah perilaku yang dijumpai pada teori atribusi oleh Fritz Heider. Teori atribusi Fritz Heider dalam Rizkiyah et al. (2020), merupkan suatu metode untuk mengevaluasi bagaimana cara pandang seseorang terhadap perilaku diri mereka sendiri dan orang lain. Dengan kata lain teori atribusi adalah bagaimana suatu individu menjelaskan penyebab dari perilaku yang ada disekitar mereka (Weiner, 2010). Perilaku suatu individu ditentukan oleh atribusi internal dan atribusi eksternal. Atribusi internal ditentukan oleh sifat, karakter, dan sikap dari individu itu sendiri. Disisi lain, atribusi eksternal dipengaruhi oleh situasi atau keadaan.

Relevansi teori atribusi dengan penelitian ini terletak pada penentuan sikap patuh atau tidak patuh oleh WPOP untuk memenuhi kewajiban perpajakannya yang dipengaruhi oleh atribusi internal maupun atribusi eksternal. Intensi WPOP untuk menerapkan e-filling dalam pelaporan SPT, erat kaitannya dengan perilaku WPOP yang disebabkan oleh dorongan eksternal. Kepatuhan WPOP disebabkan pula oleh atribusi eksternal melalui peran relawan pajak yang dipercayai mampu memberi kontribusi positif.

\section{Kepatuhan Pajak}

Mayoritas pemerintahan di seluruh dunia secara berkesinambungan berupaya meningkatkan kepatuhan pajak warga negaranya (Jimenez \& Iyer, 2016). Kepatuhan pajak atau tax compliance dapat didefinisikan sebagai kemauan WP untuk tunduk terhadap regulasi perpajakan di suatu negara (Mohamad et al., 2010). Kepatuhan pajak dapat berlandaskan kepercayaan atau kekuasaan otoritas. Kepatuhan pajak berlandaskan kepercayaan akan bermuara pada kepatuhan sukarela. Sedangkan kepatuhan berlandaskan kekuasaan akan berujung pada kepatuhan yang dipaksakan (Kirchler et al. 2008; Wahl et al., 2010).

Kepatuhan pajak terdiri dari dua jenis kepatuhan, yaitu kepatuhan formal dan kepatuhan material (Tambun \& Kopong, 2017). WP dikatakan patuh secara formal ketika WP telah memenuhi kewajiban perpajakannya sesuai dengan ketentuan perpajakan. Hal ini ditandai dengan dilakukannya penyampaian SPT sesuai dengan jangka waktu yang telah diatur dalam undang-undang, sedangkan kebenaran isi SPT yang telah dilaporkan menandakan WP telah patuh secara substantif atau material.

Sebagai negara yang menganut $S A S$, kepatuhan pajak menjadi salah satu faktor terpenting dalam penerimaan serta pelaksanaan kewajiban perpajakan. Pasalnya, WP diwajibkan untuk menghitung, menyetor, dan melaporkan sendiri kewajiban perpajakannya. Menurut Kaur (2016) SAS mendorong WP untuk mampu menilai dan melaporkan kewajiban perpajakannya dengan benar. Artinya WP dituntut untuk setidaknya memiliki pengetahuan akan pajak yang memadai (Saad, 2014). Namun, Wicaksono \& Lestari (2017) berpendapat untuk mencapai kepatuhan pajak sebenarnya tidak diperlukan pengetahuan pajak yang mendalam, yang lebih penting adalah pengetahuan WP akan hukum pajak. Tentunya keberhasilan $S A S$ tidak akan tercapai tanpa kolaborasi dan komunikasi yang baik antara otoritas pajak dengan WP. Sistem ini akan berjalan baik jika pihak yang terlibat memiliki tingkat kepatuhan sukarela yang tinggi (Sarkar \& Kumar, 2016).

Seiring dengan pesatnya perkembangan teknologi, tentunya kebutuhan WP terus berkembang. Berhubungan dengan hal tersebut, DJP perlu senantiasa memperhatikan kepuasan WP agar peningkatan kepatuhan tercapai (Artawan, 2020). Oleh karena itu DJP melakukan beberapa penyesuaian terhadap kebijakankebijakan dan layanan merka dengan 
memanfaatkan perkembangan teknologi yang terjadi. Wujudnya dapat ditemui pada layanan-layanan elektronik berbasis teknologi informasi yang diantaranya adalah: e-faktur, e-registration, e-SPT, ebilling, e-filling dan yang terbaru yakni $e$ objection.

\section{E-filling}

E-filling merupakan suatu sistem pelaporan SPT atau penyampaian pemberitahuan perpanjangan SPT Tahunan dengan menggunakan sarana internet yang dilakukan secara online dan real time. Menurut Azmi \& Lee Bee (2010) biaya yang dikeluarkan WP akan lebih ringan karena dengan e-filling pelaporan sudah paperless. Hal tersebut berbeda dengan penelitian oleh Eichfelder \& Hechtner (2018) yang tidak menemukan signifikansi penerapan e-filling terhadap penurunan biaya. Lepas dari itu, kualitas informasi, kualitas sistem e-filling, dan kualitas layanan merupakan faktor penting untuk mencapai kepuasan dari WP pengguna layanan e-filling (Solichah et al., 2019). Namun, menurut WPOP pengguna e-filling, fitur yang tersedia dalam e-filling masih belum lengkap (Saragih \& Septamia, 2019). Artinya optimalisasi dari sistem e-filling masih perlu dilakukan.

Penggunaan e-filling sangat dipengaruhi oleh persepsi kemudahan dan persepsi kegunaan (Motwani, 2015). Carter et al. (2014) berpendapat bahwa WP yang percaya dengan opsi pelaporan pajak secara elektronik daripada manual akan lebih cenderung mengadopsi e-filling. Ibrahim (2014) menambahkan bahwa penggunaan e-filling dapat menghemat waktu WP yang sudah berpengalaman dalam mengoperasikannya, sedangkan akan memakan lebih banyak waktu bagi mereka yang awam. Hal ini merupakan kesenjangan yang terjadi dari penerapan e-filling. Namun kesenjangan tersebut dapat diatasi dengan mengadakan pelatihan-pelatihan kepada WP dalam upaya meningkatkan kepatuhan pajak (Night \& Bananuka, 2019). Pelatihan dan pendampingan sangat dibutuhkan dalam penerapan e-filling, sehingga mendorong WP untuk terus memanfaatkan teknologi ini (Bhuasiri et al., 2016). Otoritas pajak juga perlu memberi perhatian pada para mahasiswa dengan melakukan roadshow di kampus mereka. Utamanya mahasiswa tingkat akhir sebagai calon WPOP potensial yang dalam waktu dekat memiliki kemungkinan untuk melakukan pembayaran pajak dan lapor SPT melalui e-filling (Islam, 2012).

\section{Relawan Pajak}

Program relawan pajak adalah salah satu program yang dapat membantu pemerintah untuk membentuk WP potensial yang bertanggung jawab di masa mendatang melalui pendalaman pengetahuan pajak. Hal ini sesuai dengan penelitian Newman et al. (2018). Adanya sinergi dan kesadaran pajak yang kuat diantara DJP, perguruan tinggi, dan mahasiswa mendorong terciptanya program relawan pajak.

Pelaksanaan program ini searah dengan penelitian Tambunan \& Rosdiana (2020) yang menyatakan bahwa perlu adanya peningkatan kuantitas SDM otoritas pajak Indonesia dalam mengikuti perkembangan bisnis, bersama-sama dengan optimalisasi sistem informasi. Saat dilaksanakannya program relawan pajak, mahasiswa bertugas untuk memberi asistensi kepada WPOP dalam melaporkan SPT Tahunannya, baik itu SPT 1770 S maupun SPT 1770 SS via $e$ filling. Dengan adanya asistensi yang layak terhadap layanan e-filling, maka secara bertahap WP akan terbiasa untuk melaporkan pajaknya secara daring (Chen, 2010).

\section{Pengaruh penerapan e-filling Terhadap Kepatuhan WPOP}

E-filling sebagai wujud investasi DJP dalam kemajuan teknologi, dari tahun ke tahunnya terus menunjukkan peningkatan kuantitas pengguna. Namun pada kenyataannya tidak sedikit juga yang masih belum mengerti mengakses dan memanfaatkan fasilitas ini. Seperti yang diungkapkan Kaniskha et al. (2016) faktor penghambat penerapan $e$ filling yakni, kurangnya pengetahuan WP 
tentang teknologi dan perpajakan, jaringan internet, dan banyak WP masih ragu-ragu dalam memanfaatkan $e$-filling.

Pada penelitian yang dilakukan oleh Wijaya et al., (2019) di KPP Pratama Jambi berkesimpulan bahwa penerapan e-filling berpengaruh positif signifikan terhadap kepatuhan WP. Hal tersebut senada dengan penelitian oleh Sentanu \& Budiartha (2019) dan juga penelitian oleh Tambun \& Kopong (2017). Namun, penelitian yang dilakukan di Zimbabwe Revenue Authority (ZIMRA) oleh Sifile et al. (2018) berpendapat berbeda. Penelitian tersebut menyatakan bahwa e-filling tidak memastikan kepatuhan pajak, karena hanya meningkatkan pelaporan pajak bukan pembayaran pajak. Begitu pula dengan penelitian oleh Blaufus et al., (2019), yang tidak mengkonfirmasi layanan e-filling mampu untuk mengurangi biaya kepatuhan, sehingga tidak ada pengaruh terhadap kepatuhan WP.

$\mathrm{H} 1$ : Penerapan $e$-filling berpengaruh positif terhadap kepatuhan WPOP.

\section{Pengaruh Peran Relawan Pajak Terhadap Kepatuhan WPOP}

Relawan pajak merupakan program yang diluncurkan DJP sebagai upaya peningkatan kepatuhan WPOP. Berdasarkan penelitian yang dilakukan oleh Nabila et al. (2019), disebutkan bahwa relawan pajak berpengaruh terhadap peningkatan kepatuhan WP yang tercermin dari peningkatan penerimaan SPT di tiga lokasi asistensi. Di samping itu, Dwianika \& Sofia (2019) menambahkan bahwa pelatihan pajak yang efektif dan efisien untuk relawan pajak dapat mftaempengaruhi kepuasan WP yang berpengaruh pada kepatuhan masyarakat urban secara signifikan. Walaupun hal tersebut mengindikasikan hal positif, bertolak belakang dengan penelitian oleh Fort et al. (2006) yang beranggapan bahwa
Program VITA yang merupakan program sejenis relawan pajak memicu terjadinya ketergantungan WP. Apabila dengan hadirnya relawan pajak memberikan WPOP kemudahan dalam menyelesaikan kewajiban perpajakan mereka, maka WPOP akan patuh.

H2 : Relawan pajak berpengaruh positif terhadap kepatuhan WPOP.

Moderasi Peran Relawan Pajak atas Penerapan E-filling Terhadap Kepatuhan WPOP

Kemudahan yang ditawarkan dari program relwan pajak diharapkan mampu untuk membentuk kepatuhan pajak sukarela WP, khususnya bagi mereka yang memperoleh asistensi dan sukarelawan yang tergabung dalam relawan pajak. Penelitian terkait Tax Volunteer yang memiliki keterkaitan erat dengan relawan pajak salah satunya dilakukan oleh Lim et al. (2012) yang menyimpulkan bahwa perlu adanya peningkatan pengguna dan ketersediaan dari Program VITA di Amerika Serikat. Hal ini dikarenakan VITA merupakan sumber daya vital bagi keluarga berpenghasilan rendah Namun, WP berpenghasilan rendah di sana masih kurang memanfaatkannya dan banyak pula yang tidak mengetahui keberadaan dari program tersebut. Hal ini mengindikasikan bahwa keberadaan VITA masih belum mampu menjangkau WP yang paling membutuhkan. Apabila WPOP berpendapat bahwa relawan pajak dapat meningkatkan kompetensi mereka dalam melaksanakan kewajiban perpajakannya di masa yang akan datang khususnya dalam hal ini yaitu pemanfaatan e-filling secara mandiri. Maka WP akan cenderung patuh dikarenakan dari persepsi kemudahan dan kegunaannya.

H3 : Moderasi relawan pajak dapat memperkuat pengaruh penerapan e-filling terhadap kepatuhan WPOP. 


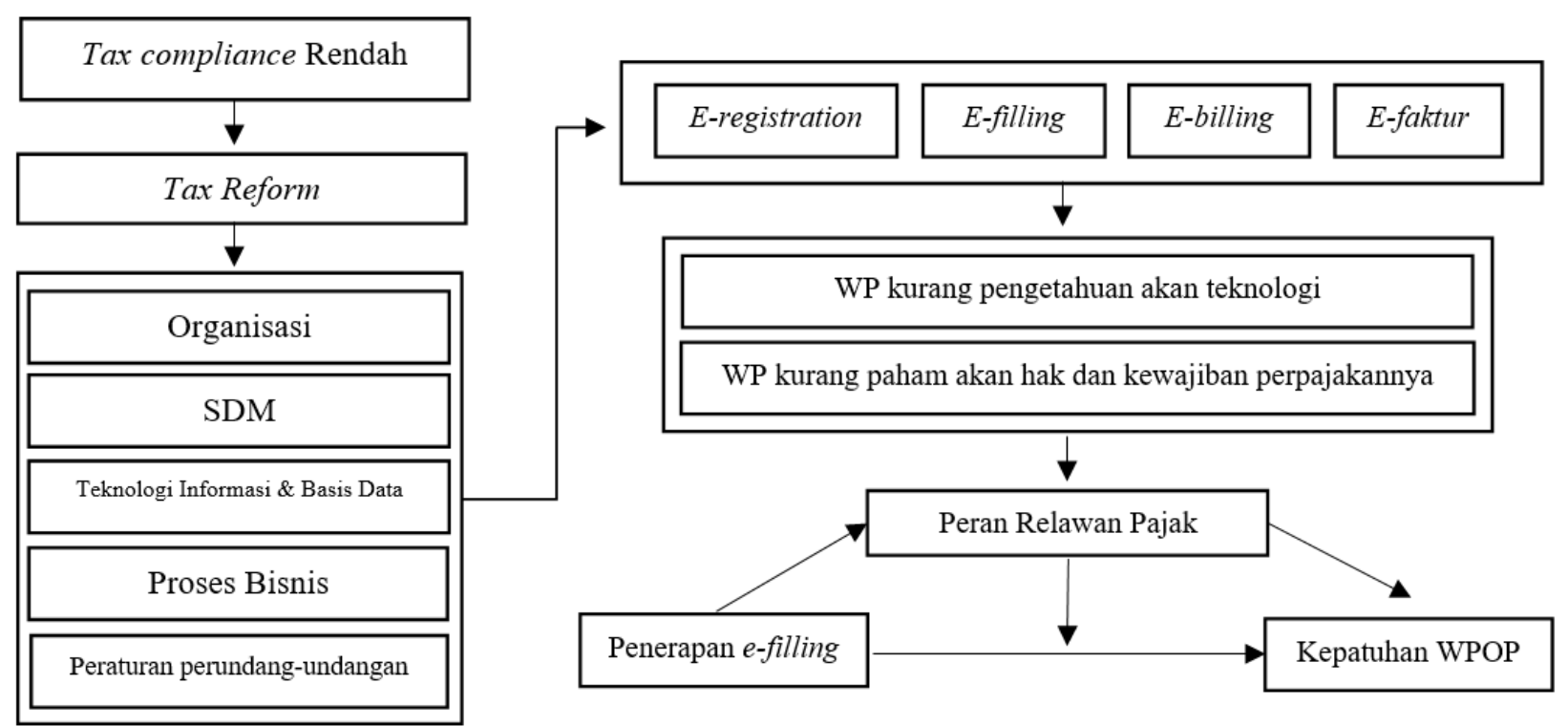

\section{Gambar 2. Kerangka Konseptual}

\section{METODE PENELITIAN}

Penelitian ini merupakan penelitian kuantitatif. Penelitian kuantitatif merupakan penelitian yang berupaya untuk mengukur fenomena sosial dengan mengumpulkan dan menganalisis data numerik, serta fokus untuk menjelaskan bagaimana variabelvariabel saling berinteraksi. Data yang digunakan dalam penelitian ini merupakan data primer melalui kuesioner yang disusun menggunakan Google Forms. Kuesioner disebarkan selama 15 hari yang dimulai pada tanggal 19 Juni 2020 hingga 2 Juli 2020 melalui media sosial seperti Telegram dan Whatsapps. Pernyataan dalam penelitian ini berjumlah 21 pernyataan. Di antaranya diukur menggunakan indikator yang dikembangkan oleh Adm (2018), khususnya pada variabel e-filling dan kepatuhan WPOP. Sedangkan, variabel relawan pajak memuat pernyataan yang merupakan adaptasi dari penelitian oleh Miller \&
Thalacker (2013). Oleh karena adanya perbededaan konteks dalam penelitian, maka pernyataan dalam kuesioner mengalami beberapa penyesuaian.

Populasi penelitian ini diantaranya adalah WPOP yang terdaftar baik itu pada KPP Pratama Badung Selatan, KPP Pratama Gianyar, KPP Pratama Singaraja dan KPP Pratama Tabanan. Pertimbangannya adalah keempat KPP tersebut merupakan lokasi asistensi Relawan Pajak Tax Center Politeknik Negeri Bali. Metode pengumpulan sampel yang ditentukan bersifat tidak acak (non-probability sampling) dengan teknik penarikan sampel yaitu purposive sampling sebanyak 100 sampel. Data yang dikumpulkan merupakan sampel dari sejumlah populasi yang dipilih berdasarkan kriteria, yakni WPOP yang memperoleh asistensi relawan pajak dan/atau WPOP pengguna e-filling yang mengetahui adanya relawan pajak.

Tabel 1. Definisi Operasional

\begin{tabular}{lll}
\hline Variabel & Indikator & $\begin{array}{l}\text { Jumlah } \\
\text { pertanyaan }\end{array}$ \\
\hline \multirow{3}{*}{ Kepatuhan WPOP } & (1) Pengetahuan dasar perpajakan & 2 \\
(KP) (Adm, 2018) & (2) Menyelesaikan kewajiban tepat waktu & 2 \\
& (3) Perhitungan pajak terutang & 1 \\
& (4) Fasilitas & 1 \\
Penerapan $e$-filling (EF) (Adm, & (5) Tanggungjawab atas tunggakan & 1 \\
\hline
\end{tabular}




\begin{tabular}{lll}
\hline 2018$)$ & (2) Manfaat penggunaan & 2 \\
& (3) Efisiensi dan Efektifitas & 3 \\
& (1) Kemudahan pelaporan & 1 \\
& (2) Edukasi perpajakan & 2 \\
& (3) Sosialisasi & 1 \\
Peran relawan pajak (RP) & (4) Kemandirian WPOP & 2 \\
(Miller \& Thalacker, 2013) & (5) Kepuasan WPOP & 1 \\
\hline
\end{tabular}

Sumber: Adm (2018), Miller \& Thalacker (2013).

\section{Analisis Data}

Analisis data dalam penelitian ini menggunakan metode Structural Equation Modeling (SEM) dengan pendekatan Partial Least Square (PLS), yang mana digunakan aplikasi SmartPLS 3.0. Dalam metode PLS dilakukan dua model pengujian, yakni measurement model dan structural model. Dalam measurement model dilakukan uji validitas dan uji reliabilitas. Setelah itu pada structural model, dilakukan uji hipotesis melalui nilai probability value yang dihasilkan dengan prosedur bootstrapping.

\section{HASIL PENELITIAN}

Pada bagian hasil dan pembahasan diawali dengan penyajian karakteristik responden. Dari 100 responden, sebanyak 76 orang diantaranya menyatakan bahwa ia pernah memperoleh asistensi relawan pajak dan sisanya merupakan WPOP pengguna $e$ filling yang mengetahui adanya relawan pajak. Agar lebih mudah dipahami karakteristik responden disajikan dalam Tabel 2.

Tabel 2. Karakteristik Responden

\begin{tabular}{lcc}
\hline Keterangan & Frekuensi & Presentase \\
\hline Jenis Kelamin & 57 & $57 \%$ \\
Laki-Laki & 43 & $43 \%$ \\
Perempuan & & \\
Usia & 29 & $29 \%$ \\
18 - 24 Tahun & 23 & $23 \%$ \\
25 - 34 Tahun & 38 & $38 \%$ \\
35 - 44 Tahun & 10 & $10 \%$ \\
45 - 60 Tahun & & \\
Pendapatan & 29 & $29 \%$ \\
1 - J Juta & 21 & $21 \%$ \\
3 - Juta & 40 & $40 \%$ \\
- J Juta 7 Juta & 10 & $10 \%$ \\
Terdaftar Pada & & $49 \%$ \\
KPP Pratama Badung Selatan & 49 & $8 \%$ \\
KPP Pratama Gianyar & 8 & $15 \%$ \\
KPP Pratama Singaraja & 15 & $28 \%$ \\
KPP Pratama Tabanan & 28 & \\
\hline
\end{tabular}

Sumber: Data primer yang diolah, 2020

\section{Evaluasi uji validitas dan reliabilitas}

Evaluasi measurement model, harus dibedakan antara indikator formatif dan refleksif. Dalam penelitian ini hubungan antara konstruk dengan indikator merupakan hubungan yang refleksif. Hubungan refleksif dalam measurement model dinilai dengan memperhatikan nilai validitas dan reliabilitas (Hair et al., 2011). Evaluasi validitas dalam penelitian ini menggunakan convergent validity dan discriminant validity. Corvergent validity dari 
measurement model dengan reflektif indikator dinilai berdasarkan korelasi antara item score atau component score dengan construct score yang dihitung dengan menggunakan PLS. Berdasarkan rule of thumb, nilai yang biasanya digunakan untuk menilai convergent validity yaitu nilai loading factor harus lebih dari 0.7 serta nilai average variance extracted (AVE) harus lebih besar dari 0.5 (Hair et al., 2011).

Uji reliabilitas dari data konstruk dapat dilihat dari nilai cronbach's alpha dan composite reliability. Apabila suatu konstruk mempunyai nilai cronbach's alpha dan composite reliability yang lebih besar dari 0,7 maka konstruk tersebut dinyatakan reliabel (Hair et al., 2011). Guna memperoleh nilai-nilai tersebut dilakukan dengan menjalankan prosedur PLS Algorithm. Pada Gambar 3 dan Gambar 4, ditunjukkan model hasil dari perhitungan dengan prosedur PLS Algorithm

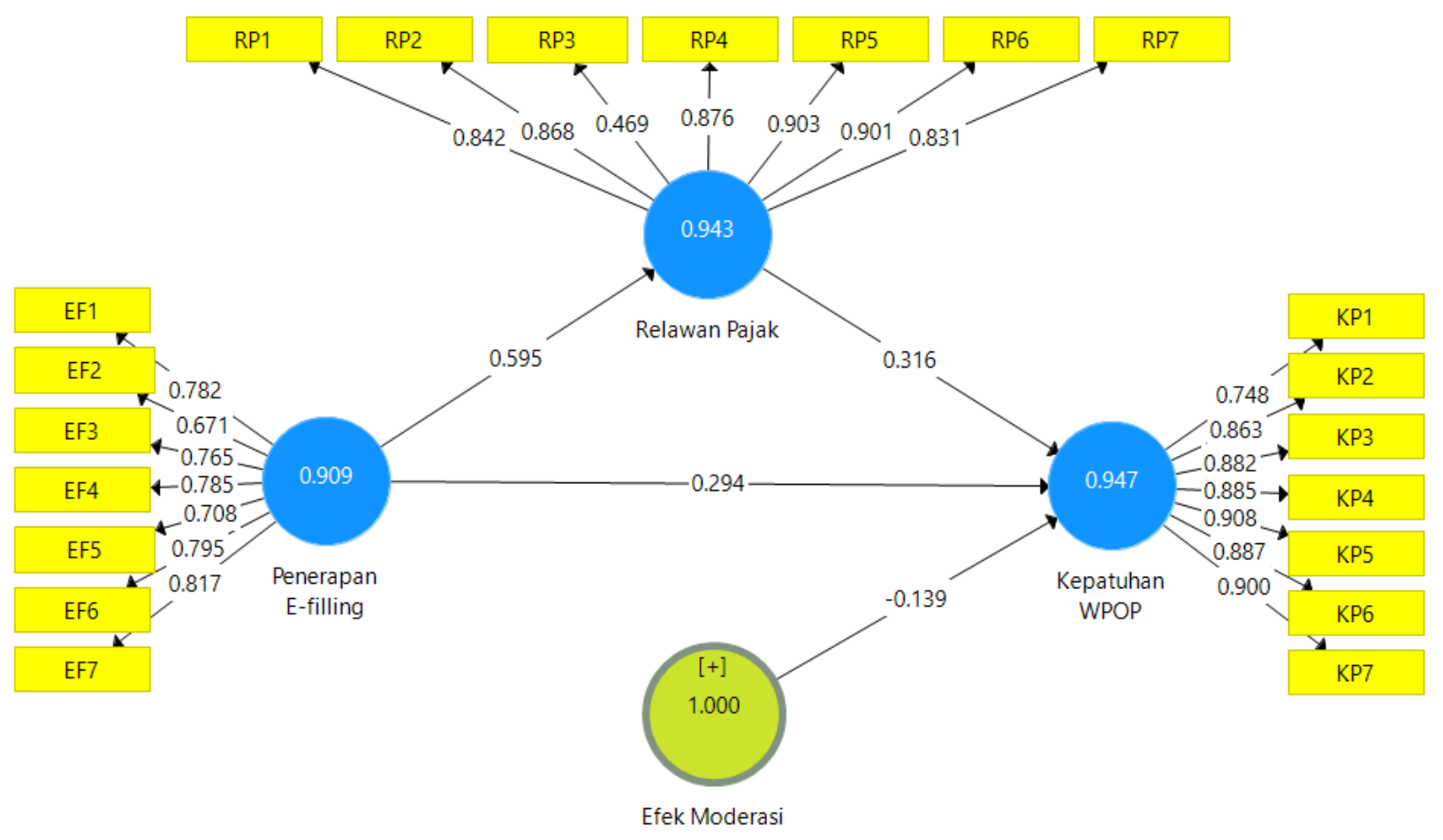

Gambar 3. Model Sebelum Lolos Uji Validitas dan Reliabilitas

Sumber: SmartPLS 3.0, 2020

Pada Gambar 3, ada 2 item yang belum memenuhi nilai loadings factor yang diantaranya: RP3 dan EF2. Artinya harus dilakukan perhitungan kembali melalui prosedur PLS Algorithm dengan menghapus kedua item tersebut. Namun, setelah perhitungan lanjutan ternyata hal tersebut mempengaruhi nilai loadings factor EF5 yang menjadi semakin kecil dan dibawah 0,7. Hal ini menyebabkan harus dilakukan perhitungan ketiga dengan menghapus EF5. Hasil akhir perhitungan dengan menggunakan prosedur PLS Algorithm dapat dilihat pada Gambar 4. 


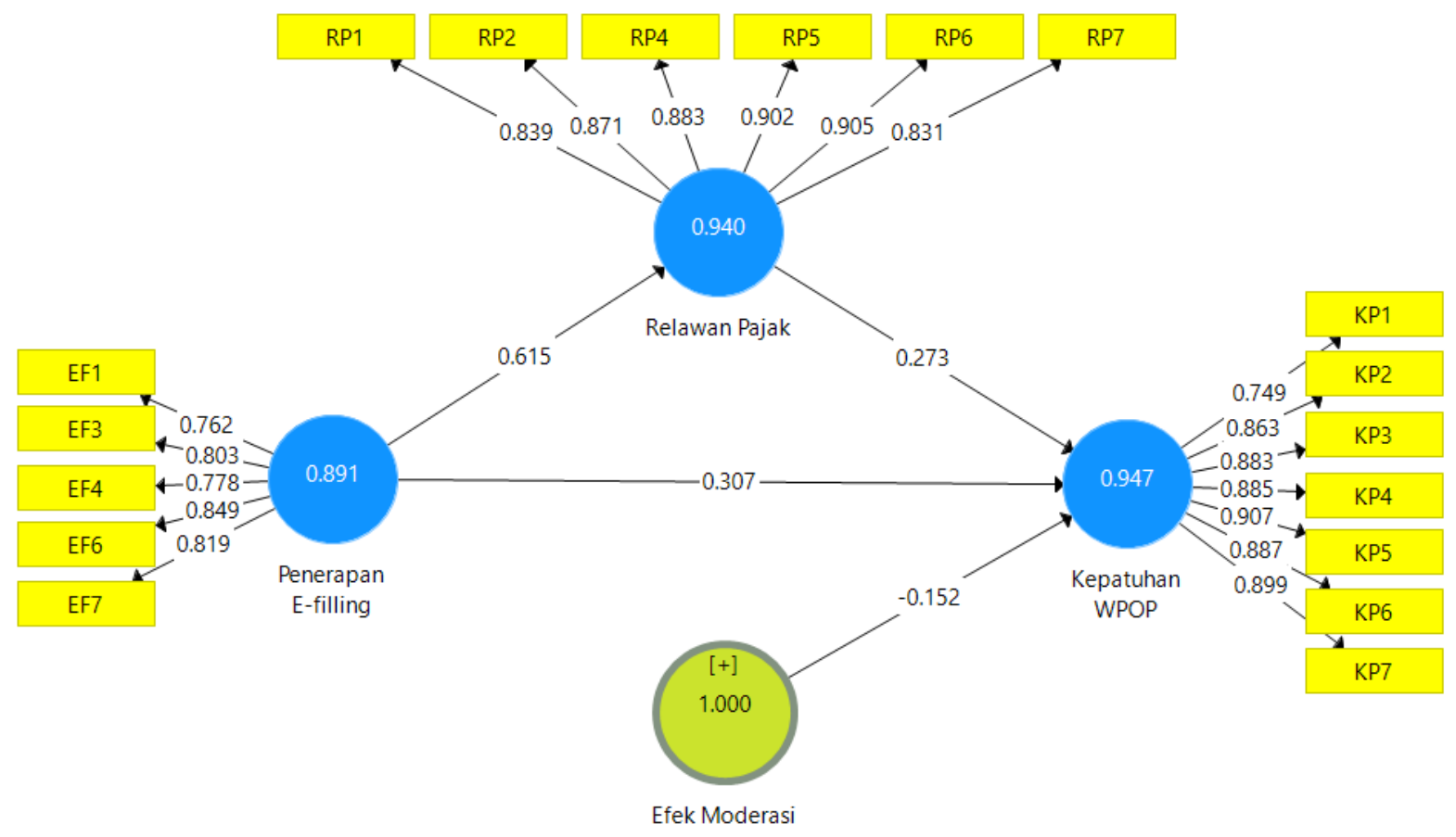

Gambar 4. Model Setelah Lolos Uji Validitas dan Reliabilitas

Sumber: SmartPLS 3.0, 2020

Masih pada convergent validity, semua nilai $A V E$ untuk tiap konstruk pada Gambar 4, telah bernilai di atas 0,5 sehingga model tersebut telah memenuhi syarat convergent validity. Nilai $A V E$ dapat dilihat pada Tabel 3.

Tabel 3. Nilai Average Extracted Variance

\begin{tabular}{cc}
\hline Variabel Laten & Average Variance Extracted (AVE) \\
\hline Kepatuhan WPOP & 0,755 \\
Penerapan e-filling & 0,644 \\
Peran relawan pajak & 0,763
\end{tabular}

Sumber: SmartPLS 3.0, 2020 (diolah oleh penulis)

Pengujian validitas selanjutnya dilakukan dengan pengujian discriminant validity. Pengujian ini dilakukan dengan melihat nilai cross loading setiap item konstruk terhadap konstruknya, yang mana harus lebih besar daripada korelasi item konstruk lainnya. Hasil cross loading dari setiap item disajikan dalam Tabel 4.

Tabel 4. Nilai Cross Loading

\begin{tabular}{lllll}
\hline & EF & KP & RP & ME \\
\hline EF1 & $\mathbf{0 . 7 6 2}$ & 0.483 & 0.320 & -0.361 \\
EF3 & $\mathbf{0 . 8 0 3}$ & 0.482 & 0.416 & -0.393 \\
EF4 & $\mathbf{0 . 7 7 8}$ & 0.484 & 0.376 & -0.425 \\
EF6 & $\mathbf{0 . 8 4 9}$ & 0.668 & 0.590 & -0.640 \\
EF7 & $\mathbf{0 . 8 1 9}$ & 0.725 & 0.646 & -0.685 \\
KP1 & 0.601 & $\mathbf{0 . 7 4 9}$ & 0.565 & -0.594 \\
KP2 & 0.647 & $\mathbf{0 . 8 6 3}$ & 0.631 & -0.714 \\
KP3 & 0.631 & $\mathbf{0 . 8 8 3}$ & 0.634 & -0.677 \\
KP4 & 0.601 & $\mathbf{0 . 8 8 5}$ & 0.673 & -0.709 \\
\hline
\end{tabular}




\begin{tabular}{lllll}
\hline KP5 & 0.676 & $\mathbf{0 . 9 0 7}$ & 0.651 & -0.681 \\
KP6 & 0.613 & $\mathbf{0 . 8 8 7}$ & 0.654 & -0.685 \\
KP7 & 0.679 & $\mathbf{0 . 8 9 9}$ & 0.662 & -0.703 \\
RP1 & 0.390 & 0.550 & $\mathbf{0 . 8 3 9}$ & -0.506 \\
RP2 & 0.582 & 0.597 & $\mathbf{0 . 8 7 1}$ & -0.629 \\
RP4 & 0.525 & 0.684 & $\mathbf{0 . 8 8 3}$ & -0.627 \\
RP5 & 0.573 & 0.630 & $\mathbf{0 . 9 0 2}$ & -0.591 \\
RP6 & 0.579 & 0.650 & $\mathbf{0 . 9 0 5}$ & -0.642 \\
RP7 & 0.543 & 0.717 & $\mathbf{0 . 8 3 1}$ & -0.645 \\
ME & $-0,700$ & -0.784 & -0.656 & $\mathbf{1 , 0 0 0}$ \\
\hline
\end{tabular}

Catatan: ME: Efek Moderasi

Sumber: SmartPLS 3.0, 2020

Dapat diamati pada Tabel 4 bahwa nilai cross loading dari seluruh konstruk terhadap konstruknya lebih besar daripada korelasi item dari suatu konstruk ke konstruk lainnya. Berdasarkan hasil pengujian tersebut, menunjukkan bahwa hasil perhitungan telah memenuhi pengujian discriminant validity. Selain menggunakan angka cross loading dalam pengujian discriminant validity, pengujian dilakukan dengan membandingkan nilai square root of AVE setiap konstruk dengan korelasi antar konstruk dengan konstruk lainnya dalam model. Bila akar kuadrat $A V E$ tiap konstruk lebih besar daripada nilai korelasi antar konstruk dengan konstruk lainnya dalam model, maka model tersebut memiliki discriminant validity yang baik. Korelasi antar konstruk dengan mengkuadratkan nilai $A V E$ ditampilkan pada Tabel 5

Tabel 5. Nilai Korelasi Antar Konstruk

\begin{tabular}{lllll}
\hline & ME & KP & EF & RP \\
ME & $\mathbf{1 . 0 0 0}$ & & & \\
KP & -0.784 & $\mathbf{0 . 8 6 9}$ & & \\
EF & -0.656 & 0.732 & $\mathbf{0 . 8 0 3}$ & $\mathbf{0 . 8 7 2}$ \\
RP & -0.700 & 0.736 & 0.615 & \\
\hline
\end{tabular}

Sumber : SmartPLS 3.0, 2020

Berdasarkan Tabel 5, nilai akar kuadrat AVE dari suatu konstruk lebih besar daripada korelasi antar konstruk sehingga dapat disimpulkan bahwa pengujian discriminant validity telah terpenuhi. Setelah uji validitas terpenuhi, selanjutnya dilakukan evaluasi uji reliabilitas. Lebih detailnya nilai cronbach's alpha dan composite reliability yang digunakan untuk uji reliabilitas disajikan pada pada Tabel 6.

Tabel 6. Nilai Cronbach's Alpha dan Composite Reliability

\begin{tabular}{ccc}
\hline Variabel Laten & Cronbach's Alpha & Composite Reliability \\
\hline Kepatuhan WPOP & 0.945 & 0.956 \\
Penerapan e-filling & 0.865 & 0.900 \\
Peran relawan pajak & 0.937 & 0.950 \\
\hline
\end{tabular}

Sumber : SmartPLS 3.0, 2020

Hasil dari perhitungan pada Tabel 6, menunjukkan bahwa seluruh variabel memiliki nilai cronbach's alpha di atas
0,7. Selain itu, nilai dari composite reliability seluruh variabel dalam Tabel 6 ternyata memiliki nilai di atas 0,7 . 
Berdasarkan hasil tersebut, dapat disimpulkan bahwa seluruh variabel memiliki reliabilitas yang tinggi.

Pengujian Hipotesis

Probability value yaitu salah satu bagian dari structural model yang berguna untuk mengetahui signifikansi dari variabel- variabel yang ada. Nilai probability value yang lebih kecil dari 0,05 mengindikasikan suatu hubungan antar variabel berpengaruh signifikan. Hasil perhitungan dengan prosedur bootstrapping dilihat pada Tabel 7.

Tabel 7. Hasil Bootstrapping

\begin{tabular}{llll}
\hline Model & Path Coefficient & $\begin{array}{l}\text { Probability } \\
\text { Value }\end{array}$ & Signifikansi \\
\hline (H1) EF -> KP (b1) & 0.273 & 0.035 & Signifikan \\
(H2) RP -> KP (b2) & 0.307 & 0.005 & Signifikan \\
(H3) ME -> KP (b3) & -0.152 & 0.058 & Tidak Signifikan \\
\hline
\end{tabular}

Sumber : SmartPLS 3.0, 2020

Tabel 7 menunjukkan bahwa berdasarkan analisis data menggunakan aplikasi SmartPLS 3.0, terdapat 2 hipotesis yang diterima dan 1 hipotesis yang ditolak. Hipotesis yang diterima meliputi, H1 dan $\mathrm{H} 2$. Artinya hubungan penerapan e-filling terhadap kepatuhan WPOP berpengaruh positif signifikan dan hubungan langsung antara peran relawan pajak terhadap kepatuhan WPOP juga berpengaruh positif signifikan. Sedangkan, hipotesis yang ditolak yakni H3. H3 merupakan pengujian moderasi, yang mana menurut Sharma et al. (1981) jika koefisien b2 dinyatakan signifikan dan koefisien b3 tidak signifikan maka dapat dinyatakan variabel moderasi tersebut masuk ke dalam jenis prediktor moderasi. Artinya variabel relawan pajak hanya berperan sebagai variabel eksogen/independen.

\section{PEMBAHASAN}

Sebagai pilar utama penerimaan negara, pajak perlu menjadi prioritas pemerintah agar terwujud kesejahteraan sosial di masyarakat. Pemerintah wajib meningkatkan pelayanan umum sehingga WP merasakan manfaat pembayaran pajak, sehingga simpulan penelitian Faisal \& Yulianto (2019) bisa terjawab. Populasi WP di Indonesia yang besar, khususnya WPOP menjadikan otoritas pajak sangat tergantung dengan tingkat kepatuhan sukarela mereka guna menggapai target penerimaan pajak. Sejalan dengan hal tersebut, rasa percaya masyarakat akan pajak sangat dibutuhkan, karena melalui hal tersebut pemerintah akan mampu untuk membangun kepatuhan pajak sukarela di masyarakat dalam hal ini WPOP. Di samping itu, guna membangun rasa percaya masyarakat, otoritas pajak harus berusaha memberikan perubahan yang sejalan dengan perkembangan kebutuhan WPOP melalui reformasi pajak yang efektif.

Tuntutan di era digital saat ini, mengantarkan otoritas pajak untuk memenuhi kebutuhan WPOP berupa efisiensi dari pemenuhan kewajiban perpajakan mereka. Guna memenuhi hal tersebut otoritas pajak yakni DJP, telah melakukan banyak pembenahan dalam sistem administrasi perpajakan di Indonesia. Satu diantara pembenahan tersebut ialah peningkatan dalam segi sistem pelaporan pajak.

Pelaporan pajak yang semula manual telah diberi opsi untuk dilakukan secara daring melalui e-filling. Melalui perubahan tersebut, stigma administrasi pajak yang rumit secara perlahan akan sirna dengan sendirinya. Walaupun begitu, masyarakat yang masih belum memanfaatkan fasilitas tersebut tidaklah sedikit. Bagi mereka yang memiliki akses yang minim terhadap internet, tentu sangat sulit untuk membiasakan diri. Begitu juga bagi 
beberapa WPOP yang sudah terkategori lansia, tidak keseluruhannya memandang bahwa mereka perlu untuk beradaptasi terhadap perkembangan teknologi. Zaidi et al. (2017) juga menerangkan bahwa kemampuan WPOP dalam pengoperasian komputer mampu mempengaruhi pandangannya akan adanya teknologi online system yang mudah digunakan, sehingga meningkatkan kepuasan pengguna dan WPOP tersebut cenderung berkeinginan untuk menerapkan online system tersebut. Menyikapi hal tersebut, DJP secara berkesinambungan melakukan sosialisasi pajak, menyediakan layanan baru, memupuk inklusi kesadaran pajak dikalangan pelajar, dan tidak luput juga penyelenggaraan program relawan pajak.

Langkah DJP lainnya untuk menumbuhkan kepatuhan sukarela WP adalah melalui sosialisasi perpajakan. Sosialisasi yang telah dilakukan DJP dikemas dalam bentuk media cetak dan elektronik serta dalam bentuk seminar perpajakan, seperti seminar tentang kebijakan, program-program baru, dan bahkan pengisian e-filling. Dengan dilakukannya sosialisasi yang efektif mencerminkan DJP sebagai otoritas pajak telah berusaha untuk menanamkan pola pikir WP yang positif terhadap perpajakan di Indonesia. Namun pada kenyataannya melalui sosialisasi tidak serta merta kepatuhan WP akan meningkat. Menanamkan pola pikir atau mindset yang positif terhadap perpajakan pada WP membutuhkan komitmen dan waktu yang lama. Menyadari hal ini, DJP melaksanakan suatu upaya peningkatan kepatuhan WP jangka panjang melalui program inklusi kesadaran pajak yang dilakukan secara bertahap. Menurut website edukasi pajak, program inklusi kesadaran pajak merupakan usaha yang dilakukan oleh DJP bersama dengan kementerian yang membidangi pendidikan untuk meningkatkan kesadaran perpajakan peserta didik, guru, dan dosen yang dilakukan dengan integrasi materi kesadaran pajak dalam kurikulum, pembelajaran, dan perbukuan. Program ini nantinya diharapkan bisa untuk melahirkan generasi sadar pajak yang merasa malu jika tidak melaksanakan kewajiban perpajakannya dengan benar.

Pentingnya memupuk kesadaran pajak sejak dini, juga mendorong DJP untuk bekerjasama dengan perguruan tinggi melalui tax center. Alasannya, sumber daya yang dimiliki oleh perguruan tinggi tentunya berpeluang untuk menjadikan tax center sebagai mitra strategis DJP dalam membangun kesadaran, kepedulian, dan kepatuhan WP. Masih berkaitan dengan upaya untuk meningkatkan kepatuhan WP, baru-baru ini DJP berkolaborasi dengan tax center peruguran tinggi di Indonesia untuk melaksanakan suatu program pengabdian mahasiswa kepada masyarakat dalam program relawan pajak.

\section{Penerapan E-filling berpengaruh terhadap peningkatan Kepatuhan WPOP}

Setelah dilakukan analisis data, dalam penelitian ini dinyatakan bahwa variabel penerapan $e$-filling berpengaruh positif dan signifikan terhadap kepatuhan WPOP. Hasil ini menunjukkan bahwa penerapan e-filling mampu meningkatkan kepatuhan WPOP dalam melaporkan SPT Tahunan. Artinya semakin banyak WPOP yang menerapkan e-filling dalam melaporkan SPT Tahunannya, maka kepatuhan WPOP juga akan cenderung mengalami peningkatan. Hasil tersebut senada dengan penelitian yang dilakukan oleh Sentanu \& Budiartha (2019) dan Tambun \& Kopong (2017) .

Kemudahan dari penggunaan e-filling akan mampu menghilangkan beban WPOP untuk melaporkan pajaknya. Sebelumnya, WPOP masih perlu mendatangi KPP untuk melakukan pelaporan, hal ini tentu menguras biaya, waktu dan energi dari WPOP itu sendiri. Setelah adanya e-filling, pelaporan disederhanakan sedemikian rupa. Pelaporan dapat dilakukan di mana saja dan kapan saja asalkan tersedia 
jaringan internet yang memadai. Bahkan penelitian yang dilakukan oleh Kaniskha et al. (2016), berkesimpulan bahwa penerapan e-filling dapat menumbuhkan suatu kepatuhan sukarela bagi WP. Namun jika ditinjau secara psikologis, tidak semua WPOP mau menerapkannya dalam melakukan pelaporan SPT. Maka dari itu, guna melancarkan proses administrasi perpajakan, DJP tetap memberikan opsi untuk melaporkan secara manual.

Hasil penelitian ini tidak sejalan dengan beberapa penelitian yang dilakukan oleh peneliti terdahulu, yakni diantaranya penelitian oleh Sifile et al. (2018) yang menyimpulkan bahwa penerapa e-filling tidak mampu memastikan kepatuhan WP. Begitu juga dengan penelitian oleh (Defitri \& Fauziati, 2018) yang menjelaskan bahwa penerapan e-filling tidak berpengaruh terhadap peningkatak kepatuhan pajak.

Relawan Pajak berpengaruh terhadap peningkatan Kepatuhan WPOP

Pada penelitian ini dinyatakan bahwa variabel relawan pajak berpengaruh positif dan signifikan terhadap kepatuhan WPOP. Hasil tersebut menunjukkan bahwa peran relawan pajak mampu mengarahkan WPOP menuju kepatuhan. Hal ini sama dengan kesimpulan yang diutarakan oleh Nabila et al. (2019), yang menyebutkan bahwa melalui kegiatan relawan pajak terjadi peningkatan kepatuhan WP yang tercermin dari tercapainya target penerimaan SPT Tahunan pada 3 KPP lokasi asistensi. Namun, hasil dari penelitian ini tidak searah dengan penelitian oleh Pradnyani \& Utthavi (2020) yang menyebutkan bahwa tidak ada dampak yang signifikan dari efektivitas realwan pajak terhadap jumlah WP yang melapor SPT di KPP Pratama Badung Selatan.

Keuntungan yang dihasilkan dari program relawan pajak juga memberikan efek positif kepada para sukarelawan yakni mahasiswa. Mahasiswa yang lolos seleksi, akan diberikan pelatihan pengetahuan serta softskill yang berguna dalam proses asistensi. Melalui pelatihan tersebut maka mahasiswa yang tergabung dalam program relawan pajak atau sejenisnya akan mengalami peningkatan dalam ilmu terapan, kemampuan penyelesaian masalah, serta keterampilan dalam berkomunikasi (Aldridge et al., 2015). Artinya program relawan pajak dapat dikatakan sebagai sebuah kesempatan besar bagi mahasiswa untuk mengimbangi teori dan praktik yang telah didapatkan selama bangku kuliah pada situasi yang sesungguhnya (Strupeck \& Whitten, 2004).

Antusiasme mahasiswa dan dosen yang berkontribusi pada pelaksanaan Relawan Pajak Tax Center Politeknik Negeri Bali patut diapresisasi. Walaupun di tahun 2020 program ini hanya berlangsung selama 14 hari, menurut data KP2KP Kerobokan, Relawan Pajak Tax Center Politeknik Negeri Bali telah berhasil memberi asistensi kepada sebanyak 2.110 WPOP. Berdasarkan jumlah tersebut $72 \%$ diantaranya memperoleh asistensi pengisian SPT Tahunan dengan jenis formulir 1770 SS dan sisanya memperoleh asistensi jenis formulir $1770 \mathrm{~S}$. Artinya mayoritas WP yang diasistensi Relawan Pajak Tax Center Politeknik Negeri Bali ialah mereka yang berpenghasilan maksimal 60 juta rupiah per tahun.

Penelitian ini meyakini bahwa jenis dari kepatuhan WP yang mampu dipengaruhi oleh peran relawan pajak yakni hanya kepatuhan secara administratif atau kepatuhan formal. Alasannya, karena tugas utama dari program relawan pajak yakni asistensi WPOP dalam pelaporan pajak. Ini artinya kepatuhan secara teknis atau material WPOP belum dijamin dalam pelaksanaan program ini. Namun lepas dari itu, program ini nyatanya mampu memberikan kontribusi yang besar bagi otoritas pajak dalam mengatasi lonjakan jumlah WP. Hal ini sesuai dengan kesimpulan dari penelitian Tambunan \& Rosdiana (2020) yang mengharapkan 
adanya peningkatan dari kapasitas sumber daya manusia otoritas pajak.

\section{Relawan Pajak Bukan merupakan Moderator dari Penerapan E-filling dan Kepatuhan WPOP}

Pada penelitian ini dinyatakan bahwa variabel peran relawan pajak sebagai moderasi, berpengaruh negatif tidak signifikan atas penerapan e-filling terhadap kepatuhan WPOP. Hasil penelitian ini mengindikasikan bahwa, variabel peran relawan pajak bukan merupakan variabel yang memoderasi pengaruh penerapan e-filling terhadap kepatuhan WPOP. Penelitian ini menilai hal tersebut terjadi karena memang relatif sulit untuk menanamkan kemandirian WPOP secara langsung hanya melalui asistensi relawan pajak untuk menggunakan e-filling. Apalagi mengingat mayoritas pengguna jasa asistensi berusia lebih tua dari pada para relawan. Hal ini membuktikan kebenaran bahwa kepatuhan WPOP dipengaruhi oleh atribusi eksternal maupun atribusi internal.

Dapat dikatakan bahwa eksistensi dari relawan pajak sendiri hampir sama seperti petugas pajak yang melayani pelaporan SPT pada umumnya. Justru dengan adanya relawan pajak memunculkan kemungkinan untuk membuat WP ketergantungan, seperti yang diutarakan oleh Fort et al., (2008). Hal ini sejalan dengan kesimpulan dalam penelitian relawan pajak oleh Dwianika \& Sofia (2019) yang menyebutkan bahwa banyak masyarakat mengharapkan kegiatan serupa akan terus berlanjut di masa yang akan datang.

\section{KESIMPULAN DAN SARAN \\ Kesimpulan}

Hubungan antara variabel penerapan $e$ filling dengan kepatuhan WPOP menunjukkan adanya pengaruh yang positif signifikan. Semakin tinggi penerapan e-filling di kalangan WPOP, maka WPOP akan memiliki kecenderungan untuk patuh memenuhi kewajiban perpajakannya yakni dalam hal pelaporan SPT. Mengingat pentingnya manfaat yang diperoleh WPOP dalam penggunaan $e$-filling. Sedangkan pengaruh antara variabel peran relawan pajak terhadap kepatuhan WPOP secara langsung berpengaruh positif signifikan. Semakin tinggi peran relawan pajak akan mengarahkan WPOP kepada peningkatan kepatuhan mereka secara administratif. Namun, penelitian ini menyimpulkan bahwa peran relawan pajak dalam mengasistensi WPOP, belum mampu memoderasi hubungan positif antara penerapan e-filling terhadap kepatuhan WPOP. Variabel peran relawan pajak justru merupakan variabel yang berdiri sendiri, karena tergolong dalam prediktor moderasi.

\section{Saran}

Kepatuhan pajak tidak mampu tumbuh jika dibangun tanpa komitmen dari WP dan otoritas pajak. Adanya komitmen dari kedua belah pihak merupakan cerminan keberhasilan otoritas pajak dalam mengupayakan peningkatan penerimaan negara jangka panjang. Komitmen WPOP untuk memanfaatkan fasilitas yang diberikan otoritas pajak diharapkan mampu menumbuhkan kesadaran pajak bagi WPOP. Apabila fasilitas tersebut belum mampu menjawab permasalahan mereka, WPOP dapat memanfaatkan layanan kring pajak.

Dalam kaitannya dengan e-filling, WPOP haruslah memfasilitasi dirinya dengan jaringan internet yang stabil dan tidak melakukan pelaporan pada jam-jam sibuk, guna memaksimalkan pengalaman pemakaian e-filling. Sistem e-filling yang telah menjadi alat bantu otoritas pajak dalam pengarsipan dokumen pajak WP masih perlu diberikan perhatian oleh otoritas pajak. Di samping itu, program relawan pajak sebaiknya lebih berfokus pada edukasi pajak untuk WP, mengingat pentingnya edukasi serta guna mencegah ketergantungan WP terhadap asistensi relawan pajak. 
Penelitian ini tidak luput dari keterbatasan, penelitian berikutnya diharapakan dapat menganalisis kembali pengaruh peran relawan pajak terhadap kepatuhan WPOP. Dengan pertimbangan untuk menambahkan jumlah responden, melakukan pengembangan indikator, penambahan variabel, menambah kuantitas item pertanyaan, serta menyebarkan kuesioner secara langsung saat berlangsungnya program relawan pajak agar mendapat hasil yang lebih akurat. Alternatif lainnya bisa menggunakan mix method, yang merupakan perpaduan metode kuantitatif dan kualitaitf. Variabel peran relawan pajak dalam mengasistensi WPOP, yang belum mampu memoderasi hubungan positif antara penerapan e-filling terhadap kepatuhan WPOP dapat digali lebih dalam dengan melakukan pendekatan kualitatif.

\section{DAFTAR PUSTAKA}

Adm, S. (2018). The Effect of Applying EFilling Applications towards Personal Taxpayer Compliance in Reporting Annual Tax Returning (SPT) in Bengalis State Polytechnic Indonesia. International Journal of Public Finance, 3(1), 47-62. https://doi.org/10.30927/ijpf.432848

Aldridge, R., Callahan, R. A., Chen, Y., \& Wade, S. R. (2015). Income Tax Preparation Assistance Service Learning Program: A Multidimensional Assessment. Journal of Education for Business, 90(6), 287-295. https://doi.org/10.1080/08832323.201 5.1034065

Artawan, I. G. P. (2020). The Effect of Service Quality to Build Taxpayer Trust and Satisfaction on Increasing Taxpayer Compliance in Gianyar Regency. International Journal of Contemporary Research and Review, 11(09), 21868-21883. https://doi.org/10.15520/ijcrr.v11i09. 842
Asrinanda, Y. D. (2018). The Effect of Tax Knowledge, Self Assessment System, and Tax Awareness on Taxpayer Compliance. International Journal of Academic Research in Business and Social Sciences, 8(10), 539-550.

https://doi.org/10.6007/IJARBSS/v8i10/4762

Azmi, A. C., \& Lee Bee, N. (2010). The Acceptance of the e-Filing System by Malaysian Taxpayers: a Simplified Model. Electronic Journal of EGovernment, 8(1), 13-22. http://www.ejeg.com/issue/download. html?idArticle $=162$

Bharti Motwani, S. H. (2015). Behavioral Intention of Taxpayers towards Online Tax Filing in India: An Empirical Investigation. Journal of Business \& Financial Affairs, 04(01), 1-5. https://doi.org/10.4172/21670234.1000135

Bhuasiri, W., Zo, H., Lee, H., \& Ciganek, A. P. (2016). User Acceptance of egovernment Services: Examining an e-tax Filing and Payment System in Thailand. Information Technology for Development, 22(4), 672-695. https://doi.org/10.1080/02681102.201 6.1173001

Blaufus, K., Hechtner, F., \& Jarzembski, J. K. (2019). The Income Tax Compliance Costs of Private Households: Empirical Evidence from Germany. Public Finance Review, 47(5), 925-966. https://doi.org/10.1177/10911421198 66147

Boneck, R., Barnes, J. N., \& Stillman, T. F. (2014). VITA Experiential, Service-Learning, Learned Competencies, And Changed Mindsets. Journal of College Teaching \& Learning (TLC), 11(2), 71-84.

https://clutejournals.com/index.php/T LC/article/view/8545

Carter, L., McFadden-Wade, G., \& Wells, 
J. T. (2016). Exploring the Impact of Organizational Citizenship Behavior on Perceptions of E-Filing Success. International Journal of Public Administration in the Digital Age, 3(1), 43-52. https://doi.org/10.4018/IJPADA.2016 010103

Carter, L., Schaupp, L. C., \& Mcbride, M. E. (2011). The U.S. e-File Initiative: An Investigation of the Antecedents to Adoption from the Individual Taxpayers' Perspective. E-Service Journal, 7(3), 2-19. http://www.jstor.org/stable/10.2979/e servicej.7.3.2 .

Chen, C. W. (2010). Impact of quality antecedents on taxpayer satisfaction with online tax-filing systems-An empirical study. Information and Management, 47(5-6), 308-315. https://doi.org/10.1016/j.im.2010.06.0 05

Darmayasa, I. N. (2019). Preskriptif Ketentuan Umum Perpajakan Dalam Perspektif Akuntansi Pancasila. Jurnal Akuntansi Multiparadigma. https://doi.org/10.18202/jamal.2019.0 4.10002

Darmayasa, I. N., Sudarma, I. M., Achsin, H. M., \& Mulawarman, A. D. (2018). Constructed interpretation of tax compliance through the historicity, rationality, and actuality of pancasila (cases in Indonesia). International Journal of Trade and Global Markets, 11(1-2), 67-76. https://doi.org/10.1504/IJTGM.2018. 092481

Defitri, S. Y., \& Fauziati, P. (2018). The effect of demographic factors and efilling usage on tax compliance. International Journal of Engineering and Technology(UAE), 7(3), 156158.

https://doi.org/10.14419/ijet.v7i3.25.1 7535

Dwianika, A., \& Sofia, I. P. (2019). Relawan Pajak: Bagaimana Pelatihan
Pajak Mempengaruhi Kepuasan Wajib Pajak Pada Masyarakat Urban? (Studi Pada Tax Centre Universitas Pembangunan Jaya). Keberlanjutan, 4(2), 1176-1191. https://doi.org/10.32493/keberlanjuta n.v4i2.y2019.p1176-1191

Eichfelder, S., \& Hechtner, F. (2018). Tax Compliance Costs: Cost Burden and Cost Reliability. Public Finance Review, 46(5), 764-792. https://doi.org/10.1177/10911421176 91603

Faisal, M., \& Yulianto, A. (2019). Religiusitas, Norma Subjektif dan Persepsi Pengeluaran Pemerintah dalam Mendukung Kepatuhan Wajib Pajak. Jurnal Kajian Akuntansi, 3(2), 170.

https://doi.org/10.33603/jka.v3i2.310 6

Fenochietto, R., \& Pessino, C. (2013). Understanding Countries' Tax Effort. IMF Working Papers, 2013(244), 130.

https://doi.org/10.5089/97814843012 72.001

Fort, C. P., Reider, B., \& Jones, B. L. (2008). The Volunteer Income Tax Assistance Student Program: Are We Creating a Dependence on the Service? Journal of Higher Education Outreach and Engagement, 12(3), 129-138.

https://ojsprod.galib.uga.edu/jheoe/art icle/view/500

Hastuti, S., Suryaningrum, D. H., Pembangunan, U., Veteran, N., \& Timur, J. (2014). Implementation of Decomposed Theory of Planned Behavior on the Adoption of EFilling Systems Taxation Policy in Indonesia. Expert Journal of Business and Management, 2(1), 1-8. https://ideas.repec.org/a/exp/bsness/v 2y2014i1p1-8.html

Ibrahim, I. (2014). The Compliance Time Costs of Malaysian Personal Income Tax System: E-filers vs. Manual- 
filers. Procedia - Social and Behavioral Sciences, 164(August), 522-527.

https://doi.org/10.1016/j.sbspro.2014. 11.141

Jimenez, P., \& Iyer, G. S. (2016). Tax compliance in a social setting: The influence of social norms, trust in government, and perceived fairness on taxpayer compliance. Advances in Accounting, 34, 17-26. https://doi.org/10.1016/j.adiac.2016.0 7.001

Kaniskha, B., Mangesti Rahayu, S., \& Dwi Avianto, G. (2016). Analisa Peranan E-Filing Dalam Rangka Meningkatkan Kepatuhan Pelaporan Surat Pemberitahuan Tahunan Wajib Pajak Orang Pribadi (Studi Pada Kantor Pelayanan Pajak Pratama Malang Selatan). Jurnal Perpajakan (JEJAK), $\quad 9(1), \quad$ 1-8. http://perpajakan.studentjournal.ub.ac .id/index.php/perpajakan/article/view/ 261

Kaur, G. (2016). Self-Assessment System of Taxation as a Challenge for India. International Journal of Advanced Education and Research, 1(3), 9-11. http://www.ijstr.org/finalprint/dec2019/The-Impact-Of-Selfassessment-System-Ontax-PaymentThrough-Tax-Control-AsModeration-Variables.pdf

Kementerian Keuangan Republik Indonesia. (2020). Nota Keuangan II beserta RAPBN. In Nota Keuangan beserta Anggaran Pendapatan dan Belanja Negara Tahun 2020 (Issue Defisit dan Pembiayaan Anggaran). https://www.kemenkeu.go.id/media/1 4041/nota-keuangan-beserta-apbn-ta2020.pdf

Kirchler, E., Hoelzl, E., \& Wahl, I. (2008). Enforced versus voluntary tax compliance: The "slippery slope" framework. Journal of Economic Psychology, 29(2), 210-225. https://doi.org/10.1016/j.joep.2007.05
.004

Lim, Y., Dejohn, T. V., \& Murray, D. (2012). Free tax assistance and the earned income tax credit: Vital resources for social workers and lowincome families. Social Work (United States), 57(2), 175-184. https://doi.org/10.1093/sw/sws035

MD. Aminul Islam,. (2012). Factors affecting user satisfaction in the Malaysian income tax e-filing system. African Journal of Business Management, 6(21), 6447-6455. https://doi.org/10.5897/ajbm11.1689

Mohamad, M. H., Ahmad, N., \& Sakarnor Bin Deris, M. (2010). The Relationship Between Perceptions and Level of Compliance Under Self Assessment System - a Study in the East Coast Region. Journal of Global Business and Economics, 1(1), 241257.

https://econpapers.repec.org/article/gr g01biss/v_3a1_3ay_3a2010_3ai_3a1 3ap 3a241-257.htm

Nabila, D. T. Della, S, I. D. K. Y., \& Manan, A. (2019). Edukasi Penggunaan E-Filing Melalui Program Relawan Pajak 2019. 1(2), 217-222.

https://jwd.unram.ac.id/index.php/jwd /article/view/58

Newman, W., Mwandambira, N., Charity, M., \& Ongayi, W. (2018). Literature review on the impact of tax knowledge on tax compliance among small medium enterprises in a developing country. Journal of Legal, Ethical and Regulatory Issues, 22(4), 4675.

https://www.researchgate.net/publicat ion/330998304_Literature_review_on the_impact_of_tax_knowledge_on_t ax_compliance_among_small_mediu m_enterprises_in_a_developing_coun try

Night, S., \& Bananuka, J. (2019). The Mediating Role of Adoption of an Electronic Tax System in the 
Relationship Between Attitude Towards Electronic Tax System and Tax Compliance. Journal of Economics, Finance and Administrative Science, 25(49), 7388. https://doi.org/10.1108/JEFAS07-2018-0066

Nurwanah, A., Sutrisno, T., Rosidi, R., \& Roekhudin, R. (2018). Determinants of tax compliance: Theory of planned behavior and stakeholder theory perspective. Problems and Perspectives in Management, 16(4), 395-407.

https://dx.doi.org/10.0.84.7/ppm.16(4 ).2018.33

Palil, M. R. (2010). Tax Knowledge and Tax Compliance Determinants in Self Assessment System in Malaysia. Journal of International Development, 4(3), 61-1. https://core.ac.uk/download/pdf/7610 7.pdf

Palil, M. R. (2011). Factors affecting tax compliance behaviour in self assessment system. African Journal of Business Management, 5(33), 12864-12872. https://doi.org/10.5897/ajbm11.1742

Pradnyani, N. L. P. N. A., \& Utthavi, W. H. (2020). The effectiveness of tax volunteers in increasing taxpayer compliance. 9(5), 281-284. https://doi.org/10.20525/ijrbs.v9i5.82 6

Rizkiyah, R., Kusumawati, A., \& Amiruddin. (2020). The Factors that Effect Taxpayer Compliance by Using Environment as the Moderating Variable. The Factor Effect Taxpayer Compliance By Using Environment As The Moderating Variable, 5(1), 509-521. https://bit.ly/2S3NCA9

Saad, N. (2014). Tax Knowledge, Tax Complexity and Tax Compliance: Taxpayers' View. Procedia - Social and Behavioral Sciences, 109(1), 1069-1075. https://doi.org/10.1016/j.sbspro.2013. 12.590

Saragih, A. H., \& Septamia, N. U. (2019). Analisis Penerimaan Pengguna EFiling Menggunakan Model Unified Theory Acceptance and Use of Technology (UTAUT). Jurnal Kajian Akuntansi, $3(1), \quad 1$. https://doi.org/10.33603/jka.v3i1.212 9

Sarkar, S., \& Kumar, M. (2016). A Critical Assessment of the Swarnajayanti Gram Swarojagar Yojana (SGSY) in India. International Research Journal of Management, IT \& Social Sciences, 3(3), 95-100. https://doi.org/10.21744/irjmis.v3i3.1 00

Sentanu, I. N. W., \& Budiartha, K. (2019). Effect of taxation modernization on tax compliance. International Research Journal of Management, IT and Social Sciences, 6(4), 207-213. https://doi.org/10.21744/irjmis.v6n4.6 83

Sharma, S., Durand, R. M., \& Gur-Arie, O. (1981). Identification and Analysis of Moderator Variables. Journal of Marketing Research. https://doi.org/10.2307/3150970

Sifile, O., Kotsai, R., Mabvure, J. T., \& Chavunduka, D. (2018). Effect of etax filing on tax compliance: A case of clients in Harare, Zimbabwe. African Journal of Business Management, 12(11), 338-342. https://doi.org/10.5897/AJBM2018.8 515

Solichah, N. N., Isnalita, \& Soewarno, N. (2019). The Effect of E-Filing Implementation, Level of Tax Comprehension, and Tax Sanction on Formal Compliance of Individual Taxpayer. 101(Iconies 2018), 293296. https://doi.org/10.2991/iconies18.2019 .58

Strupeck, C. D., \& Whitten, D. (2004). Accounting service-learning experiences and the IRS volunteer 
income tax assistance programme: A teaching note. Accounting Education, 13(1), 101-112. https://doi.org/10.1080/09639280420 00182475

Syakura, M. A., \& Baridwan, Z. (2014). Determinan Perencanaan Pajak dan Perilaku Kepatuhan Wajib Pajak Badan. Jurnal Akuntansi Multiparadigma, 5(2), 185-201. https://doi.org/10.18202/jamal.2014.0 8.5017

Tambun, S., \& Kopong, Y. (2017). The Effect of E-Filing on The of Compliance Individual Taxpayer, Moderated By Taxation Socialization. South East Asia Journal of Contemporary Business, Economics and Law, 13(1), 45-51. http://seajbel.com/wpcontent/uploads/2017/11/ACC267.pdf

Tambunan, M. R. U. D., \& Rosdiana, H. (2020). Indonesia Tax Authority Measure on Facing the Challenge in Taxing Digital Economy. The International Technology Management Review, 9(1), 1. https://doi.org/10.2991/itmr.k.200203 .001

Teza, S. D., \& Junep, A. R. (2018). Analisis persepsi wajib pajak terhadap efektifitas dan tingkat kepatuhan pelaporan pajak menggunakan e-filing. Jurnal Program Studi Pendidikan Ekonomi STKIP PGRI Sumatera Barat, 7(1), 88-94.

https://doi.org/10.22202/economica.2 018.v7.i1.2682

Wahl, I., Kastlunger, B., \& Kirchler, E.
(2010). Trust in Authorities and Power to Enforece Tax Compliance: An Empirical Analysis of the. Law and Policy, 32(4), 383-406. https://doi.org/10.1016/j.joep.2007.05 .004

Weiner, B. (2010). Attribution Theory. The Corsini Encyclopedia of Psychology, December. https://doi.org/10.1002/97804704792 16.corpsy0098

Wicaksono, M., \& Lestari, T. (2017). Effect of Awareness, Knowledge and Attitude of Taxpayers Tax Compliance for Taxpayers in Tax Service Office Boyolali. International Journal of Economics, Business and Accounting Research (IJEBAR), 1(01), 12-25. https://doi.org/10.29040/ijebar.v1i01. 236

Wijaya, R., Lutfie, \& Beatrice, A. (2019). Influence of E-filing System Implementation against Taxpayer Compliance of the Submission the Annual Notice ( SPT ) by Understanding the Internet as Moderating Variable on Office Services Tax Pratama Jambi City. 9(4), 49-56. https://doi.org/10.6007/IJARAFMS/v 9-i4/6640

Zaidi, S. K. R., Henderson, C. D., \& Gupta, G. (2017). The moderating effect of culture on e-filing taxes: evidence from India. Journal of Accounting in Emerging Economies, 7(1), 134-152. https://doi.org/10.1108/JAEE-052015-0038 